of the puerperium there was slight pyrexia up to $99^{\circ} \mathrm{F} .\left(37.2^{\circ} \mathrm{C}\right.$.) but no evidence of sepsis. The patient subsequently developed an acute retarded depression, and on August 18, 1952, the eleventh day of puerperium, was transferred to a mental hospital. Lactation had been suppressed with stilboestrol. On August 27 she developed pyrexia and a generalized macular rash. These symptoms were attributed to sensitivity to barbiturates, which were therefore discontinued. On treatment with diphenylhydramine the rash cleared up and the temperature fell to normal. On the morning of September 5 the patient's temperature rose to $101^{\circ} \mathrm{F}$. $\left(38.3^{\circ}\right.$ C.) without apparent cause. Crystalline penicillin was given intramuscularly $(600,000$ units over a period of 12 hours). That evening a macular rash was noticed, and penicillin was discontinued. Diphenylhydramine was again given. The rash, however, became more extensive and in places purpuric, and intermittent pyrexia persisted. Promethazine was therefore substituted for the diphenylhydramine, but without producing any change in the condition of the patient, who remained acutely ill. On September 11 she was noticed to be jaundiced, and laboratory investigations gave the following results: icteric index, 31 units per $100 \mathrm{ml}$.; thymol turbidity, 2.2 units per $100 \mathrm{ml}$. ; plasma albumin, $2.8 \mathrm{~g}$. per $100 \mathrm{ml}$; plasma globulin $2.2 \mathrm{~g}$. per $100 \mathrm{ml}$. On September 13 the patient was transferred to a general hospital. The following day she complained of abdominal pain. The abdomen was found to be distended and tympanitic; stools were loose and offensive and contained blood and pus. Aureomycin was given in a dose of $250 \mathrm{mg}$. six-hourly. On September 18, as there was no improvement, laparotomy was performed by $\mathrm{Mr}$. C. Charleson. At operation the whole of the transverse colon was found to be necrotic and had to be resected, the cut ends being exteriorized. Examination of the specimen removed showed acute ulceration of the mucous membrane and intense inflammatory reaction in the bowel wall extending through to the peritoneal surface. Repeated gynaecological examination during the illness had shown no abnormality, and at operation the pelvic organs were found to be healthy.

The subsequent course of the illness was a stormy one, but ultimately the patient made a satisfactory recovery and colon continuity was restored. As the skin rash cleared. there was generalized desquamation and much of the scalp hair was lost. Her mental condition slowly improved, and by the end of December she was well enough to go home. When last seen on June 26, 1953, she was well.-We are, etc.,

Perih

HARRY Stalker.

W. M. WILSON.

\section{Methyl Chloride Poisoning}

SIR,-Dr. M. M. Macrae (Journal, May 15, p. 1134) and Dr. J. Crawford (Journal, October 9, p. 870) have each recorded a case of methyl chloride poisoning, and Dr. R. G. Schulze (Journal, September 25, p. 756) has given an example of its explosiveness when mixed with air and ignited with a match. The following case, which, like Dr. Crawford's, also occurred in connexion with a refrigerator at sea, illustrates the gravity of the delayed central action and the speed with which it can develop and progress to a fatal result even after relatively mild primary symptoms.

At about 5.30 p.m. one evening in early 1941 I was called to see a naval rating who had come to the sick bay complaining of a headache. He told me that he had spent the day repairing the ship's refrigerator plant and that the headache had come on gradually during the afternoon; he also complained of feeling sick, but had not actually vomited. He was quite ready to carry on with his work if he could have an aspirin for his headache. He looked ill, however, and I examined him, but could find nothing organically wrong. I remembered noticing that his face was very pale, almost ashen in fact, and that his breath had a faint, sweetish, indefinable odour. I thought that his speech was slightly slurred, but, as I had never seen him before (I had joined the ship two days previously), I was not at all certain about this I thought that he was probably suffering from the effects of a hard day's work in a cramped and possibly badly ventilated compartment following a party ashore the previous evening. I gave him his aspirins, but, because I did not like the look of him, I put him off duty and told him to come and see me the following morning. The following morning, however, he did not appear at the sick parade and I sent for him, only to learn that he had returned to work on the refrigerator plant. He told me that his headache and nausea were better, but to me he looked very much worse. His breath still had the odour of the previous evening, which I still could not place, but I was now fairly certain of the slurring of his speech. I thought he was also slightly unsteady on his feet, but again I could not be sure of this because of the motion of the ship. I remember noticing at the time that his general appearance was as though he was slightly drunk, and I was by then fairly certain that this was caused by the inhalation of the refrigerant gas, which I was informed was methyl chloride. I kept him off duty and told him to stay on the upper deck in the fresh air. but I was not, even then, unduly worried about him.

After I had seen him I looked at the refrigerator plant, and on entering the compartment, I noticed the same sweetish odour that I had smelt in the patient's breath, but it was so faint that it would obviously become unnoticeable after breathing it for a short time. I imagined that methyl alcohol was used in the commercial preparation of the chloride and that it was the vapour of this that I was smelling, and I assumed, erroneously, that this accounted for the slurring of speech and the unsteady gait About two hours later (about 12.30 p.m.) I was called urgently to see him again. I found him comatose, and while I was examining him he began to convulse. From then on, in spite of everything, the convulsions continued with increasing frequency and severity. His coma gradually deepened and he died about 4.30 p.m., just after arrival in hospital ashore. I subsequently attended the necropsy, but I cannot remember anything abnorma being found apart from capillary engorgement throughout. I subsequently, however, learned that the pathologist had found considerable amounts of methyl chloride in all the organs sent to him for examination.

What struck me forcibly at the time was the speed with which it all happened and his relative absence of early symptoms. He died less than 24 hours after his first symptoms, and even two hours before his loss of consciousness he had told me that he felt better and had indeed been at work again. His looks, however, belied his statement, and I believe that a less conscientious man than he would have been glad to have stayed off work, particularly when ordered to do so. I think he must have had a lethal dose before I saw him first, and his return to the refrigeration plant the following morning probably did not affect the fulminating onset, except perhaps to hasten it.

I agree strongly with Dr. Macrae that this is a most dangerous substance. I would point out, however, that the Admiralty were aware of its danger and had laid down certain precautionary measures to be adopted when work was going on in refrigerator plant compartments. Dr. Crawford's case and the one I have recounted, however. show that familiarity with this gas is liable to breed contempt, and if precautions are not heeded tragedy may result. The facts mentioned herein are published by permission of the Medical Director-General of the Navy.-I am, etc.,

Twyford. Berks

T. T. BAIRD.

\section{World Population}

SIR,--I beg to differ from the views of Mr. G. K. McKee (Journal, November 6, p. 1104). Surely "love" can only make the problem worse. What we need and have not got is wisdom to use the pack of power which science has all of a sudden dumped on our hands. We "love" the backward peoples. Therefore we cannot withhold from them the benefits of preventive medicine, the semi-prevention perhaps I ought to say, which we practise in the West. And the result has been to set spinning the king-pin of all the vicious spirals which bedevil the life of economic manover-population. There is no virtue in mere numbers. Look what over-population has already done to England. the land we love so well. Towns unique in beauty have been submerged in " built-up areas "; lovely rivers poisoned; our incomparable harbours and coastal waters polluted. Agriculture has hardened into food production. Why, even those few rabbits which escaped last summer's blitz must now be rubbed out by law because they eat our food. Yet we ourselves are scratching whole counties away just to gain a bit of expendable coal. In short, the very word " development" has come to mean destruction.

And now this industrial fever has spread throughout the world. The "big game" will have to go to make room for men. Insects are "pests"; they must be sprayed. Thus the sequences of food for "lower" animals will be broken. And thus, given incredible luck, we humans may go on increasing till the cry goes for "standing room only." But 